\title{
The Influence of Hunting Activity on Haematological Parameters of Local Dogs in Tabek Panjang, Baso, West Sumatera, Indonesia
}

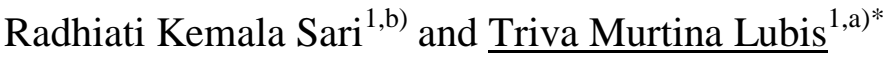 \\ ${ }^{1}$ Faculty of Veterinary Medicine \\ (Syiah Kuala University, Banda Aceh, 23111, Indonesia)

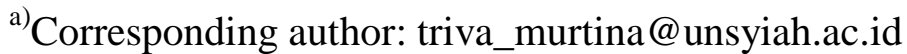 \\ b)radhiatikemalasari.ai@gmail.com
}

\begin{abstract}
This study aims to determine whether 24 hours after a physical activity such as hunting wild boars still has effects on erythrocyte counts, haemoglobin concentration, and haematocrit values of local dogs (Canis familiaris) in Tabek Panjang, Baso Subdistrict, West Sumatera, Indonesia. The study used ten healthy male local dogs, ranged 2.0-2.5 years old and $15-18 \mathrm{~kg}$. The whole blood was collected 24 hours before and after hunting in all males, then it was analyzed by a veternary haematology analyzer (Exigoeos vet Boule Medical, Swedia) in the Balai Veteriner Bukittinggi, West Sumatera. Data was statistically analyzed using T test. The results shows that the average numbers of erythrocytes 24 hours before and after hunting is $6.05 \pm 0.67 \mathrm{x} 106 / \mathrm{uL}$ and $5.15 \pm 0.79 \times 106 / \mathrm{uL}$ respectively whereas the average haemoglobin concentration 24 hours before and after hunting is $13.01 \pm 0.40 \mathrm{~g} / \mathrm{dL}$ and $12.20 \pm 0.48 \mathrm{~g} / \mathrm{dL}$. Meanwhile, the average value of haematocrit before hunting is $36.19 \pm 1.09 \%$ and it decreases to $35.43 \pm 1.14 \%$ after hunting. It can be concluded that there is a slightly decline in the erythrocyte numbers, haemoglobin concentration, and haematocrit values in local dogs 24 hours after hunting activity as a normal response of the body to maintain physiological conditions.
\end{abstract}

Keywords: local dog, erythrocyte, haemoglobin, haematocrit, hunting activity

\section{INTRODUCTION}

For Minangkabau people, hunting is an activity passed down from their ancestors (Khairani, 2011). Now, hunting is one of sports, but in the past hunting is a hobby and is one important activity that can be done by the community to secure their houses or agricultural lands from wild animals, such as wild boars (Soeprayogi, 2004). In Sumatera Barat Province, hunting is only conducted by men accompanied by their dogs that have been trained months or years for that activity (Arifin, 2012).

Dogs are one of famous companion animals known because they are very obedient to their owners and very close to humans. Also, dogs can be trained and are sociable and to raise a dog is not too difficult (Dharmojono, 2003). For the Minangkabau, dogs do not only act as pets, but also they are trained and taught how to hunt (Arifin, 2012). Dogs used for hunting is a local dogs (Canis familiaris) because the type of those dogs have a long body, strong legs, keen sense of smell and ability to run fast, moreover they are good swimmers (Untung, 1999; Octriana, 2011).

Wild boar hunting activity in West Sumatera is conducted in groups starting from morning until afternoon. The owners have to consider the health of the dog. Therefore, it is very important to care for and keep the dog in good condition and free of infectious diseases. Good and sufficient 
nutrition for health dogs should also be considered. One way to control the dog's health is by performing a blood test as a routine laboratory procedure for determining the amount of blood circulating in the body of a dog. This information assists in the diagnosis enforcement.

Physical exercise such as hunting of wild boars and treadmill exercise can affect haematology profile particularly erythrocytes counts, haemoglobin concentration and haematocrit values. In this recent study, we examine some blood parameters in local dogs after 24 hours hunting activity because we do not obtain permission from the dog owners to collect blood samples during hunting. Rovira et al. (2006) reported that exercise such as through the tunnel for 100 seconds in 15 dogs of different breeds showed a rise in the red blood cells counts and the haematocrit values in the first 0.5 minutes. And after 30 minutes, the blood collection was performed again and the values of both parameters reduced. A study conducted by Piccione et al. (2012) on untrained beagle dogs showed a decrease in the number of erythrocytes, haemoglobin level and haematocrit values in the 30 minutes after 45 minutes treadmill workout is given. Meanwhile, Saputro and Junaidi (2015) reported that in male wistar rats induced by vitamin $\mathrm{C}$ showed that the maximum physical exercise (inserting a rat in the pool) can increase both the number of erythrocytes and haemoglobin concentration after exercise in rats.

The recent study is carried out because of the limited information published about haematology profile in Indonesian local dogs. Most of Indonesian researchers compare their findings to those of foreign researchers. Also, the study aims to investigate the effects of hunting activity on blood profile of local dogs in Tabek Panjang. The results of the study can be used as a basis that physical activity given to the animals (dogs) can affect the state of physiological and laboratory parameters, such as blood profile.

\section{MATERIAL AND METHODS}

Blood samples of ten head dogs were collected twice ( 24 hours before and after hunting) under physical restraint. The medial foot of the dog then was cleaned with $70 \%$ alcohol and the whole blood was collected through saphenous veins by a $3 \mathrm{ml}$ syringe. After that, the blood was analyzed by haematology analyzer.

\section{RESULTS AND DISCUSSIONS}

In this study, erythrocyte counts in blood samples of local dogs collected 24 hours before hunting activities are in the normal range, i.e. from 5.11 to $6.96 \times 10^{6} / \mu \mathrm{L}$ of blood (Table 1 ). Number of normal erythrocytes in dogs ranged from 5.4 to $7.8 \times 10^{6} / \mu \mathrm{L}$ of blood (Meyer and Harvey, 1998); 5.5 to $8.5 \times 10^{6} / \mu \mathrm{L}$ of blood (Rebar et al., 2001) and from 5.0 to $7.9 \times 10 \% / \mu \mathrm{L}$ of blood (Cunningham, 2002). The red cell count decreases after hunting activity, ranged 4.05 to 6.02 $\mathrm{x} 10^{6} / \mu \mathrm{L}$ of blood (Table 1 ), but this rate is still within the normal range. Wirajaya (2005) reported that the average erythrocyte counts of local dogs in Jakarta and Bogor areas, Indonesia are $6.05 \pm$ $1.56 \times 10^{6} / \mu \mathrm{L}$ of blood. His report is almost the same with our finding $\left(6.05 \pm 0.67 \times 10^{6} / \mu \mathrm{L}\right.$ of blood). 
Table 1. Erythrocytes counts, haemoglobin concentration and haematocrit values in local dogs

\begin{tabular}{ccccccc}
\hline & \multicolumn{2}{c}{$\begin{array}{c}\text { Erythrocytes counts } \\
\left(\mathrm{x} 10^{6} / \mu \mathrm{L}\right)\end{array}$} & $\begin{array}{c}\text { Haemoglobin } \\
(\mathrm{g} / \mathrm{dL})\end{array}$ & \multicolumn{2}{c}{$\begin{array}{c}\text { Haematokrit } \\
(\%)\end{array}$} \\
Sample & $\begin{array}{c}\text { Before } \\
\text { Hunting }\end{array}$ & $\begin{array}{c}\text { After } \\
\text { Hunting }\end{array}$ & $\begin{array}{c}\text { Before } \\
\text { Hunting }\end{array}$ & $\begin{array}{c}\text { After } \\
\text { Hunting }\end{array}$ & $\begin{array}{c}\text { Before } \\
\text { Hunting }\end{array}$ & $\begin{array}{c}\text { After } \\
\text { Hunting }\end{array}$ \\
\hline 1 & 6.96 & 5.83 & 13.30 & 12.80 & 36.00 & 35.50 \\
2 & 5.41 & 4.05 & 13.00 & 12.60 & 35.60 & 34.90 \\
3 & 5.35 & 4.99 & 12.70 & 11.40 & 35.20 & 34.40 \\
4 & 6.27 & 6.02 & 12.60 & 12.20 & 37.20 & 37.00 \\
5 & 6.33 & 6.15 & 12.90 & 12.60 & 37.10 & 36.90 \\
6 & 5.45 & 4.25 & 13.20 & 12.00 & 35.30 & 34.60 \\
7 & 6.70 & 5.25 & 13.50 & 12.40 & 38.50 & 37.60 \\
8 & 5.11 & 4.10 & 12.70 & 11.80 & 35.00 & 34.40 \\
9 & 6.73 & 5.20 & 12.50 & 11.40 & 35.90 & 34.30 \\
10 & 6.21 & 5.61 & 13.70 & 12.60 & 36.10 & 35.40 \\
\hline Total & 60.52 & 51.45 & 130.10 & 122.00 & 361.90 & 354.30 \\
Average & 6.05 & 5.15 & 13.01 & 12.20 & 36.19 & 35.43 \\
\pm SD & 0.67 & 0.79 & 0.40 & 0.48 & 1.09 & 1.14 \\
\hline
\end{tabular}

Local dogs used in this study had haemoglobin concentration in the normal range before hunting activity, i.e. from 12.50 to $13.70 \mathrm{~g} / \mathrm{dL}$ (Table 1). According to Meyer and Harvey (1998), normal haemoglobin level in dogs was 13-19 g/dL while Rebar et al. (2001) stated 12-15 g/dL and according to Cunningham (2002) it was 12-19 g/dL. Wirajaya (2005) reported that the average haemoglobin concentration in adult local dogs ( $>2$ years old) was $18.41 \pm 4.76 \mathrm{~g} / \mathrm{dL}$. The haemoglobin concentration in blood samples taken 24 hours after hunting activity ranged from 11.40 to $12.80 \mathrm{~g} / \mathrm{dL}$. Statistically, there is a significant $(\mathrm{P}<0.05)$ decline on the average haemoglobin level after the dogs hunted boars.

Normal haematocrit values in dogs according to Meyer and Harvey (1998) was 37-54\%, Rebar et al. (2001) was 37-55\% and Cunningham (2002) was 35-57\%. The haematocrit values of local dogs 24 hours before hunting activity is in a normal range (35.0 to $38.5 \%$ ) as shown at Table 1. This finding is lower than those of three other scholars mentioned before, however it is still in the normal range. Twenty four hours after hunting activity, the average values of haematocrit declines (from 36.19 to $35.43 \%$ ). The average haematocrit values based on study conducted by Wirajaya (2005) on local dogs adult (> 2 years old) was $36.94 \pm 8.5 \%$.

Changes in the number of erythrocytes of dogs associated with exercise is influenced by the type and duration or length of training provided (Rovira et al., 2008). For the local dogs in this recent study, those changes may be affected by the level of individual activities during they hunt. Various types of exercises that can be given to dogs will also affect their blood parameters, for instance Matwichuk et al. (1999) found that there was a rise in the number of erythrocytes after 15 minutes Labrador Retrievers do a dummy thrown exercise. According to Rovira et al. (2006), the competition through the tunnel, frames, jump over the board, and a ban on dogs of different breeds can increase the number of erythrocytes after exercise for 100 seconds then blood test was performed 30 seconds after the exercise and the number of erythrocytes declined again after 30 minutes of exercise.

Moreover, the red blood cell counts of dogs are also effected by the duration or length of time of exercise. Exercise duration can elevate the numbers of erythrocytes. The study conducted by Steiss et al. (2004) in Labrador Retrievers showed that after exercise for five minutes, the dogs are ordered to run on the field with a path length of 91,100 and $192 \mathrm{~m}^{2}$ 
with a duration of 152, 141, 284 seconds respectively, the results showed that this kind of excercise will go up the numbers of red blood cells.

According to Munoz et al. (1967) and Persson (1967), some studies showed that red blood cell counts become increase during given exercises because of catecholamine stimulation of the sympathetic nerves. It can stimulate heart contractions so that the blood is circulated quickly throughout the body included into the working muscles during that exercise. This causes some erythrocytes stored in the spleen will flow into the circulatory system to fulfill needs of erythrocytes in the body, resulting in an increase in the number of erythrocytes during activities undertaken.

In the recent study, 24 hours after the local dogs finished their boar hunting activity, blood parameters investigated namely, the number of red blood cells, the level of haemoglobin, and the values of haematocrit decline compared to those of 24 hours before hunting. However, it is not indications of anemia at all because all the parameters investigated are still in a normal range for dogs. Rovira et al. (2008) said that alterations in the red blood cell numbers on dogs during or after their activitiy is a normal response to maintain the body's physiological conditions. Furthermore, Munoz et al. (1967) stated after physical activity, the number of the red blood cells reduced because of the condition of hypoxemia in the body that causes their numbers will drop in the blood vessels. These conditions will stimulate releasing erythropoietin from the kidney which has a half life of 6-9 hours, but the new red blood cells will appear after 3-5 days (Nitsche, 2004).

Haemoglobin is the oxygen-carrying compound in erythrocytes which can be measured and used as an index of chemical oxygen-carrying capacity in the blood (Smith and Mangkoewidjojo, 1998). The haemoglobin level in the blood depends on the amount of oxygen present in the body. There are some factors that affect haemoglobin concentration such as the condition of the body, gender, environment and nutrition (Erwin et al., 2013). The haemoglobin level of local dogs in this recent study may be influenced by the level of their activities during they hunt wild boars and individual variations.

The haematocrit values depend on the numbers of erythrocytes compared to total blood volume (Swenson, 1984). Some scholars believe that physical activities can influence the haematocrit values based on their studies. According to Rovira et al. (2006) dog activities for 100 seconds such as competition through the tunnels, frames, jump over the board, and the tire can increase haematocrit value in Labrador Retrievers after the first 30 seconds of blood examination and it decreased after 30 minutes. Furthermore, Piccione et al. (2012) reported that, the average haematocrit on untrained beagle dogs was higher during treadmill exercises than at the rest, it also increased 30 minutes after treadmill exercises. Angle et al. (2009) stated that elevated haematocrit was correlated with a rise in the numbers of red blood cells caused by the contraction of the spleen when the dog is given exercises.

In some studies, short-term effects of experimental exercise on haematology parameters are still unclear, where it could be due to individual differences and overdehydration before exercises. Therefore, there are still many wide opportunities to explore it. Medium-term effects and long-term of exercises in all the studies are increase of the instability of the blood characterized by lower autohaemodilution than plasma viscosity and haematocrit, as well as hormonal and metabolic changes. This situation is called sports anemia and the anemia which is not true is more appropriately called sports pseudoanaemia (Brun et al., 1998). 


\section{CONCLUSIONS}

Twenty four hours after hunting activity, the erythrocytes counts, haemoglobin concentration and haematocrit values in the local dogs (Canis familiaris) decline compared to those of before hunting, although these three variables are still within the normal range.

\section{References}

1. D. Khairani, "Health profile of hunting dogs in Palembayan districts Agam regency West Sumatra province," Thesis, Institut Pertanian Bogor, 2011.

2. H. Soeprayogi, Jurnal Antropologi 1 (2), 89-113 (2004).

3. Z. Arifin, Jurnal Humaniora 24 (1), 29-36 (2012).

4. Dharmojono, Dogs: Problems and Solutions (Penebar Swadaya, Jakarta, 2003)

5. O. Untung, Take Care and Train Dogs (Penebar Swadaya, Jakarta, 1999).

6. R. Octriana, "Raising profil of dogs and their relations with rabies incidents in Pasaman districts Pasaman regency West Sumatera province," thesis, Institut Pertanian Bogor, 2011.

7. S. Rovira, A. Munoz, and M. Benito, J. Vet. Med. Sci 69 (1), 31-35 (2006).

8. S. Rovira, A. Munoz, and M. Benito, J. Vet. Med. Sci 53 (6), 333-346 (2008).

9. G. Piccione, S. Casella, M. Panzera, C. Giannetto, and F. Fazio, Journal of Veterinaria 61 (5), 511-515 (2012).

10. D.A. Saputro and S. Junaidi, Journal of Sport Sciences and Fitness 4 (3), 32-40 (2015).

11. D.J. Meyer and J.W. Harvey, Veterinary Laboratory Medicine. Interpretation and Diagnosis $2^{\text {nd }}$ ed. (W.B. Saunders Company, Philadelphia, 1998)

12. A.H. Rebar, P.S. MacWilliams, B. Feldman, F. Metzger, R. Pollock, and J. Roche, A Guide to Hematology in Dogs and Cats. Teton NewMedia, Wyoming, 2001)

13. S.G. Cunningham, Textbook of Veterinary Physiology. $3^{\text {rd }}$ ed. (Michigan State University, Michigan, 2002)

14. Wirajaya, "Haematology profile of local dogs (Canis familiaris) in Jakarta and Bogor areas," thesis, Institut Pertanian Bogor, 2005.

15. C.L. Matwichuk, S.M. Taylor, C.L. Shmon, P.H. Kass, and G.D. Shelton, AJVR. 60 (1), 88-92 (1999).

16. J. Steiss, H.A. Ahmad, P. Cooper, and C. Ledford, J. Vet Intern Med 18 (1), 147-151 (2004).

17. A. Munoz, C. Riber, R. Santisteban, M.D. Rubio, Elaguera, and F.M. Castiuon, J. Vet. Med Sci 6 (1), 13-20 (1967).

18. S.G.B. Persson, Acta Vet. Scand. (Suppl.) 19, 9-189 (1967).

19. K.E. Nitsche, Journal of Clinical Pathology 26 (2),15-27 (2004).

20. B.J. Smith and S. Mangkoewidjojo, Raising, Breeding, and Using of Experimental Animal in the Tropics (Universitas Indonesia Press, Jakarta, 1998).

21. Erwin, N. Asmilia, Zuraida, and E.S Hadi, Jurnal Medika Veterinaria 7 (2), 98-100 (2013).

22. M.J. Swenson, Duke's Physiology of Domestic Animals. $10^{\text {th }}$ ed. (Cornell University Press, Itacha and London, 1984).

23. C.T. Angle, J.J. Wakshlag, R.L. Gillette, T. Stockol, S. Geske, T.O Adkins, and C. Gregor, Vet. Clin. Pathol 38 (1), 370-374 (2009).

24. J. S. Brun, S. Khaled, E. Raynaud, D. Bouix, J.Micallef, and A. Orsetti, Clinical Hemorheology and Microcirculation 19 (2), 89-104 (1998). 